\title{
EFEKTIVITAS PENYULUHAN KESEHATAN TERHADAP TINGKAT PENGETAHUAN IBU TENTANG GIZI SEIMBANG PADA BALITA DI KELURAHAN TINGKIR LOR, KOTA SALATIGA
}

\author{
EFFECTIVENESS OF HEALTH EDUCATION ON THE LEVEL OF \\ MATERNAL KNOWLEDGE ON BALANCED NUTRITION FOR \\ UNDER-FIVE CHILDREN IN TINGKIR LOR VILLAGE, SALATIGA
}

\author{
Farida Utaminingtyas \\ Universitas Aufa Royhan Padangsidimpuan \\ Korespondensi: diajenk.farida@gmail.com
}

\begin{abstract}
Under-five children are children who have reached the age of one year and under the age of five years. Every year more than a third of child mortality worldwide is related to malnutrition. Nutritional problems among under-five children may cause serious effects, such as failure in physical growth and development, and children with suboptimal intelligence, it can even cause infant mortality. Nutritional problems among under-five children can be avoided if mothers have sufficient knowledge about how to provide food and manage the food properly, one of which is by obtaining health education. This study aims to analyze the effectiveness of health education on the level of maternal knowledge on balanced nutrition for under-five children in the Tingkir Lor District of Salatiga. This was a Pre-Experimental study with one group pre-test and post-test design conducted among the mothers of under-five children. The samples in this study were 34 respondents, taken with a total sampling technique. The instrument used was a questionnaire. Data analysis used nonparametric statistics with the Wilcoxon test. Wilcoxon test results of signed-rank tests showed the p-value of $=0.000$ which less than $\alpha=0.05$, then $H 0$ was rejected, which meant that there was an effect of health education on the level of maternal knowledge on balanced nutrition for underfive children. In conclusion, health education on balanced nutrition for under-five students given to mothers was effective in increasing their knowledge.
\end{abstract}

Keywords: Balanced nutrition for under-five children, knowledge, counseling

\begin{abstract}
ABSTRAK
Balita adalah anak yang telah menginjak usia diatas satu tahun atau usia anak dibawah lima tahun. Setiap tahun lebih dari sepertiga kematian anak didunia berkaitan dengan masalah kurang gizi. Akibat dari masalah gizi balita dapat menyebabkan efek yang serius, seperti kegagalan pertumbuhan fisik serta tidak optimalnya perkembangan dan kecerdasan, bahkan dapat menimbulkan kematian pada balita. Masalah gizi pada balita ini dapat dihindari apabila ibu memiliki pengetahuan yang cukup tentang cara pemberian makanan dan mengatur makanan balita dengan baik, salah satunya adalah
\end{abstract}


dengan mendapatkan penyuluhan kesehatan. Penelitian ini bertujuan untuk menganalisis efektivitas penyuluhan kesehatan terhadap tingkat pengetahuan ibu tentang gizi seimbang balita di kelurahan Tingkir Lor kota Salatiga. Metode yang digunakan pada penelitian ini adalah Pra Eksperimental dengan rancangan one group pre test and post test design pada ibu balita. Sampel yang digunakan adalah sebanyak 34 responden, dengan teknik total sampling. Instrumen yang digunakan kuesioner. Analisis data menggunakan statistik nonparametrik dengan uji Wilcoxon. Hasil uji wilcoxon signed rank tests menunjukkan hasil nilai $\mathrm{p}=0,000$ lebih kecil dari $\alpha=0,05$, maka H0 ditolak yang berarti ada pengaruh penyuluhan kesehatan terhadap tingkat pengetahuan ibu tentang gizi seimbang balita. Simpulan, penyuluhan kesehatan tentang gizi seimbang pada balita yang diberikan kepada ibu efektivitas dalam meningkatkan pengetahuan.

\section{Kata kunci : Gizi seimbang balita, pengetahuan, penyuluhan}

\section{PENDAHULUAN}

Masalah stunting merupakan salah satu permasalahan yang dihadapi di dunia saat ini, khususnya di negara-negara miskin dan berkembang salah satunya Indonesia (UNICEF, 2013). Menurut Riskesdas tahun 2018 Indonesia merupakan salah satu negara dengan triple burden atau triple ganda permasalahan gizi, yaitu dengan prevalensi stunting $(30,8 \%)$, wasting atau balita kurus $(10,2 \%)$, dan overwight atau balita gemuk $(8,0 \%)$ (Kemenkes RI, 2018).

Anak Balita adalah anak yang telah menginjak usia diatas satu tahun. Menurut para ahli usia balita sebagai tahapan perkembangan anak yang cukup rentan terhadap berbagai serangan penyakit, termasuk penyakit yang disebabkan oleh kekurangan atau kelebihan asupan nutrisi jenis tertentu. Setiap tahun lebih dari sepertiga kematian anak didunia berkaitan dengan masalah kurang gizi (Kemenkes RI, 2015).

Riwayat gizi yang buruk dapat dikenali pada anak dengan perkembangannya fisik sangat lambat. Riwayat gizi buruk dapat menyebabkan pembentukan otak maupun tubuh tidak baik, dan akibatnya perkembanganya fisik sangat lambat (Novaria, 2014).

Profil Dinas Kesehatan Provinsi Jawa Tengah tahun 2018 menyebutkan bahwa Angka Kematian Balita (AKABA) sebesar 9,49 per 1.000 kelahiran hidup, menurun jika dibandingkan AKABA tahun 2017 yaitu 10,4 per 1.000 kelahiran hidup, sementara di Kota Kota Salatiga sebesar 9,8 per 1.000 kelahiran hidup, ini 
menunjukkan bahwa jumlah tersebut diatas jumlah kematian balita di Provinsi Jawa Tengah. Berdasarkan laporan dari kabupaten/kota, jumlah kasus gizi buruk dengan indikator berat badan menurut tinggi badan di Jawa Tengah tahun 2018 sebanyak 961 kasus, dan di Kota Salatiga masih ditemukan adanya 3 kasus gizi buruk pada balita (Dinkes Provinsi, 2018).

Akibat dari masalah gizi balita dapat menyebabkan efek yang serius, seperti kegagalan pertumbuhan fisik serta tidak optimalnya perkembangan dan kecerdasan, bahkan dapat menimbulkan kematian pada balita. Namun, masalah gizi pada balita ini dapat dihindari apabila ibu memiliki pengetahuan yang cukup tentang cara pemberian makanan dan mengatur makanan balita dengan baik. Sehingga pengetahuan orang tua tentang gizi merupakan kunci keberhasilan baik atau buruknya status pada balita (Notoatmodjo, 2007).

Salah satu upaya menanggulangi masalah gizi yaitu melalui peningkatan pengetahuan, sikap dan perilaku seseorang dengan melakukan penyuluhan gizi. Penyuluhan gizi merupakan suatu prinsip pemasaran yang bersifat edukatif untuk memperbaiki kesadaran gizi dan menghasilkan perilaku peningkatan gizi yang baik. Menurut penelitian Dyah (2012) menyebutkan bahwa terdapat pengaruh penyuluhan gizi terhadap peningkatan pengetahuan dan pemberian makanan tambahan yang baik untuk balita (Dyah, 2012). Penelitian ini didukung oleh hasil penelitian Sinuhaji (2018) bahwa terdapat perbedaan pengetahuan pre test dan post test dengan penyuluhan pada ibu balita tentang gizi buruk. Pemberian penyuluhan tentang gizi buruk dengan metode ceramah mampu meningkatkan pengetahuan ibu balita Maka, perlu upaya menanggulangi tingginya kasus gizi kurang atau lebih maka dibutuhkan penyuluhan gizi kepada masyarakat khususnya ibu yang lebih berperan dalam penyediaan makanan dalam keluarga.

Berdasarkan hasil studi pendahuluan yang dilakukan peneliti pada bulan Mei 2019, diperoleh hasil bahwa total jumlah balita di Tingkir Lor khususnya di RW 2 dan 3 adalah 50 balita, balita laki-laki 24 dan balita perempuan 26 . Dari informasi yang didapatkan dari bidan wilayah Tingkir Lor, menyatakan bahwa masih kurangnya minat ibu untuk melakukan kunjungan posyandu dan mengikuti penyuluhan kesehatan 
khususnya tentang gizi balita karena tidak sempat serta merasa tidak perlu.

\section{METODE}

Metode dalam penelitian ini adalah Pra Eksperimental dengan rancangan one group pres test and post test design. Variabel bebas adalah ibu balita yang diberikan penyuluhan kesehatan gizi seimbang balita adalah tingkat pengetahuan ibu balita. Populasi dalam penelitian ini adalah seluruh ibu yang datang ke posyandu dan memiliki balita di RW 02 dan RW 03 Kelurahan Tingkir Lor sebanyak 50 responden yang memenuhi kriteria inklusi Ibu yang memilki anak usia balita, hadir di Posyandu dan bersedia menjadi responden. Sampel diambil dengan sampel jenuh atau total sampling.

Pada akhir penelitian ini, jumlah total sampel yang digunakan adalah 34 responden yang memenuhi kriteria inklusi Ibu yang hadir di Posyandu dan bersedia menjadi responden. Penelitian

\section{HASIL DAN PEMBAHASAN}

A. Analisis Univariat

1. Umur Responden

Tabel 1. Karakteristik Umur Ibu pada Penyuluhan Kesehatan Terhadap Tentang Gizi Seimbang pada Balita Di Kelurahan Tingkir Lor Kota Salatiga

\begin{tabular}{|c|c|c|}
\hline Umur (th) & Jumlah & Persentase \\
\hline $20-35$ & 32 & $94,1 \%$ \\
\hline$>35$ & 2 & $5,9 \%$ \\
\hline Jumlah & 34 & $100 \%$ \\
\hline
\end{tabular}

ini dilaksanakan dimulai dari bulan Juni sampai Agustus 2019.

Proses pengambilan data dilakukan menggunakan kuisioner yang diberikan sebanyak 2 kali, yaitu sebelum dilakukan penyuluhan dan sesudah diberikan penyuluhan. Ibu balita yang bersedia menjadi responden diberikan kuisioner pra test untuk menilai pengetahuan sebelum diberikan penyuluhan. Kemudian seluruh responden diberikan penyuluhan mengenai gizi seimbang pada balita dan diberikan kembali kuisioner post test untuk menilai tingkat pengetahuan ibu sesudah diberikan penyuluhan.

Analisis data yang digunakan univariat untuk menjelaskan karakteristik responden dan masingmasing variabel yang diteliti secara deskriptif dan analisis bivariat dianalisa dengan uji statistik wilcoxon dengan tingkat signifikansi $\alpha=0,05$ untuk pengaruh penyuluhan kesehatan terhadap tingkat pengetahuan ibu. 
Pada tabel 1. didapat karakteristik subjek pada penelitian ini sesuai dengan ketentuan kriteria inklusi dan eklusi penelitian. Penelitian ini dilakukan terhadap 34 responden, dengan hasil didapatkan responden paling banyak adalah responden yang berumur 20-35 tahun sebanyak 32 responden $(94,1 \%)$.

2. Status Pendidikan

Tabel 2. Karakteristik Status Pendidikan Ibu pada Penyuluhan Kesehatan Tentang Gizi Seimbang pada Balita Di Kelurahan Tingkir Lor Kota Salatiga

\begin{tabular}{|c|c|c|}
\hline Status Pendidikan & Jumlah & Persentase \\
\hline Tamat SD & 1 & $2,9 \%$ \\
\hline Tamat SMP & 2 & $5,9 \%$ \\
\hline Tamat SMA & 27 & $79,4 \%$ \\
\hline PT & 4 & $11,8 \%$ \\
\hline Jumlah & 34 & $100 \%$ \\
\hline
\end{tabular}

Pada tabel 2. didapat karakteristik status memiliki tingkat pendidikan paling pendidikan subjek pada penelitian ini, banyak yaitu tamat SMA berjumlah 27 diperoleh hasil responden yang responden $(79,4 \%)$.

\section{Pekerjaan}

Tabel 3. Karakteristik Pekerjaan Ibu pada Penyuluhan Kesehatan Tentang Gizi Seimbang pada Balita Di Kelurahan Tingkir Lor Kota Salatiga

\begin{tabular}{lcc}
\multicolumn{1}{c}{ Pekerjaan } & Jumlah & Persentase \\
\hline Bekerja & 9 & $26,5 \%$ \\
Tidak bekerja & 25 & $73,5 \%$ \\
\hline \multicolumn{1}{c}{ Jumlah } & $\mathbf{3 4}$ & $\mathbf{1 0 0 \%}$ \\
\hline
\end{tabular}

Pada tabel 3. didapat karakteristik status bekerja sebagai karyawan swasta pekerjaan subjek pada penelitian ini, dan wirausaha, responden yang tidak diperoleh hasil responden berstatus bekerja yaitu 9 responden $(26,5 \%)$ bekerja 25 responden $(73,5 \%)$ dengan status ibu rumah tangga.

4. Status Informasi

Tabel 4. Karakteristik Status Informasi Ibu pada Penyuluhan Kesehatan Tentang Gizi Seimbang pada Balita Di Kelurahan Tingkir Lor Kota Salatiga

\begin{tabular}{lcc}
\hline \multicolumn{1}{c}{ Status Informasi } & Jumlah & Persentase \\
\hline Ya & 25 & $73,5 \%$ \\
Tidak & 9 & $26,5 \%$ \\
\hline Jumlah & $\mathbf{3 4}$ & $\mathbf{1 0 0 \%}$ \\
\hline Pada tabel 4. didapat karakteristik status & \multicolumn{2}{c}{ responden berstatus sudah memperoleh } \\
informasi subjek tentang informasi gizi & informasi yaitu 25 responden (73,5\%), \\
seimbang pada balita diperoleh hasil & responden yang tidak atau belum
\end{tabular}


memperoleh informasi 9 responden (26,5\%).

5. Sumber Informasi

Tabel 5. Karakteristik Sumber Informasi Ibu pada Penyuluhan Kesehatan Tentang Gizi Seimbang pada Balita Di Kelurahan Tingkir Lor Kota Salatiga

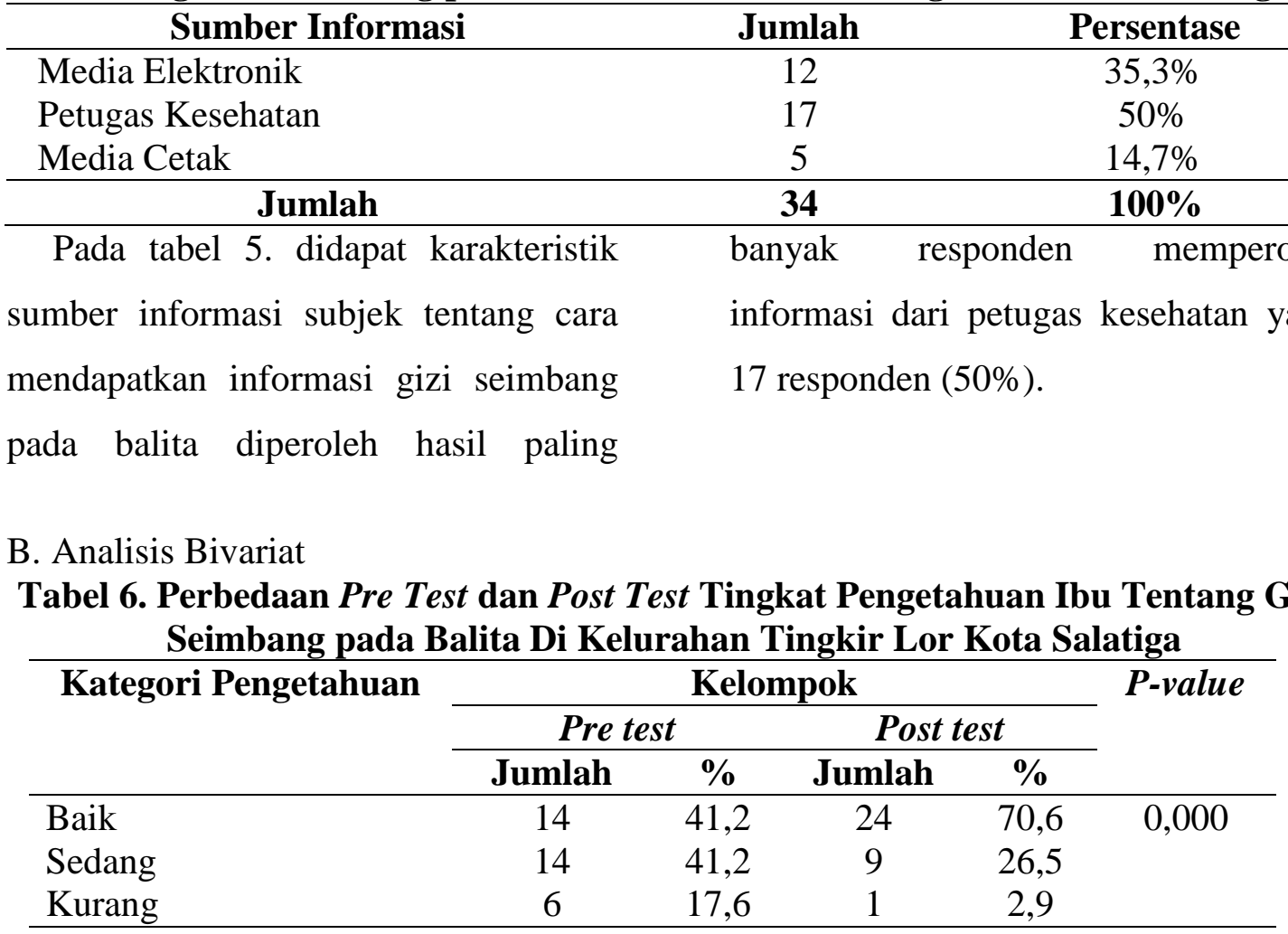

Keterangan: *Uji wilcoxon

Tabel 6. menunjukkan adanya perbedaan tingkat pengetahuan responden sebelum dan setelah diberikan penyuluhan kesehatan, terdapat 14 responden $(41,2 \%)$ dengan tingkat pengetahuan baik sebelum diberikan penyuluhan meningkat menjadi 24 responden $(70,6 \%)$, terdapat perbedaan tingkat pengetahuan sedang dan kurang jumlah responden setelah diberikan penyuluhan kesehatan 9 responden (26,5\%) dengan tingkat pengetahuan sedang dan 1 responden
$(2,9 \%)$ dengan tingkat pengetahuan kurang.

\section{Umur Responden}

Seseorang dikatakan berada pada usia reproduksi yaitu seseorang yang berada dalam kurun waktu antara 20 sampai 35 tahun. Umur akan memengaruhi terhadap daya tangkap dan pola pikir seseorang terhadap informasi yang diberikan. Dari hasil penelitian 34 responden yang diteliti, menunjukkan bahwa ibu yang memiliki anak usia balita di Posyandu Balita di 
RW 02 dan RW 03 Kelurahan Tingkir

Lor Kota Salatiga adalah ibu dengan usia reproduksi. Hasil penelitian ini sejalan menurut penelitian Susanti tahun 2013 yang menyatakan bahwa Umur juga menjadi faktor penentu dalam tingkat pengetahuan, pengalaman, keyakinan dan motivasi sehingga umur mempengaruhi perilaku seseorang terhadap objek tertentu (Susanti, 2014).

\section{Status Pendidikan}

Pendidikan seseorang akan memengaruhi cara pandangnya terhadap pengetahuan yang diperolehnya. Karena pendidikan merupakan upaya untuk memberikan pengetahuan sehingga terjadi perubahan perilaku yang positif. Menurut Notoatamodjo (2007), pendidikan memengaruhi proses belajar, makin tinggi pendidikan seseorang makin mudah orang tersebut untuk menerima informasi. Dengan pendidikan tinggi maka seseorang akan cenderung untuk mendapatkan informasi, baik dari orang lain maupun dari media massa. Semakin banyak informasi yang masuk semakin banyak pula pengetahuan yang didapat tentang kesehatan (Notoatmodjo, 2007). Dari hasil penelitian 34 responden yang diteliti, menunjukkan bahwa ibu yang memiliki anak usia balita di Posyandu
Balita di RW 02 dan RW 03 Kelurahan Tingkir Lor Kota Salatiga 79,4\% adalah tamatan SMA. Hasil penelitian ini senada dengan penelitian Azria dan Husnah pada tahun 2015 yang menemukan $(3,3 \%)$ ibu balita adalah tamatan SD, tamatan SMP $(16,7 \%)$, tamatan SMA $(53,3 \%)$, dan terdapat $(26,7 \%)$ responden yang tamat Perguruan Tinggi di Posyandu Lampaseh Aceh.

Peningkatan pengetahuan tidak mutlak diperoleh di pendidikan formal akan tetapi juga dapat diperoleh pada pendidikan non formal. Pendidikan formal ibu mempengaruhi tingkat pengetahuan ibu dimana semakin tinggi pula tingkat pengetahuan ibu untuk menyerap pengetahuan praktis dalam lingkungan formal maupun non formal terutama melalui media massa, sehingga ibu dalam mengolah, menyajikan dan membagi sesuai yang dibutuhkan (Simanjuntak, 2007). Pendidikan ibu merupakan hal dasar bagi tercapainya gizi balita yang baik. Tingkat pendidikan ibu tersebut terkait dengan kemudahan ibu dalam menerima informasi tentang gizi dan kesehatan dari luar. Menurut Susilowati dan Himawati (2017), pengetahuan yang dimiliki ibu menjadi kunci utama 
kebutuhan gizi balita terpenuhi. pengatur konsumsi makanan anggota Pengetahuan yang didasari dengan keluarga. Ibu yang bekerja tidak pemahaman yang baik dapat memiliki waktu yang cukup untuk menumbuhkan perilaku baru yang baik pula. Ibu dengan tingkat pendidikan yang lebih tinggi akan lebih mudah menerima informasi dari luar, dibandingkan dengan ibu yang memiliki tingkat pendidikan lebih rendah (Susilowati, 2017).

\section{Pekerjaan}

Pekerjaan ibu balita merupakan kegiatan ibu balita yang dilakukan di dalam maupun di luar rumah yang bertujuan untuk mendapatkan hasil. Pada penelitian ini data pekerjaan ibu dibagi menjadi 2 kategori yaitu bekerja dan tidak bekerja. Dari hasil penelitian 34 responden yang diteliti, diperoleh hasil bahwa sebagian besar responden tidak bekerja $73,5 \%$ dengan status ibu rumah tangga. Hasil penelitian ini sejalan dengan penelitian Rozali tahun 2016 yang menemukan (45\%) ibu balita bekerja, dan (55\%) ibu balita tidak bekerja di Posyandu RW 24 dan 08 Wilayah Kerja Puskesmas Nusukan Kota Surakarta (Rozali, 2016).

Menurut kepustakaan, ibu yang tidak bekerja dalam keluarga dapat memengaruhi asupan gizi balita karena ibu berperan sebagai pengasuh dan mengasuh dan merawat anaknya sehingga anaknya dapat menderita gizi kurang (Handayani, 2008).

\section{Status Informasi}

Pengetahuan akan memudahkan seseorang untuk menyerap informasi dan mengimplentasikannya dalam perilaku dan gaya hidup sehari-hari. Menurut Notoatmodjo (2007), informasi yang diperoleh baik dari pendidikan formal maupun non formal dapat memberikan pengaruh jangka pendek (immediate impact) sehingga menghasilkan perubahan atau peningkatan pengetahuan (Notoatmodjo, 2007). Dalam penelitian ini status informasi ibu dibagi menjadi 2 kategori yaitu "ya" dan "tidak". Dari hasil penelitian 34 responden yang diteliti, diperoleh hasil bahwa sebagian responden "ya" atau sudah memperoleh informasi 73,5\%, baik dari media elektronik, petugas kesehatan, serta media cetak tentang gizi balita. Peneliti belum menemukan hasil penelitian yang sejalan dengan hasil penelitian ini tentang status informasi ibu balita tentang gizi seimbang balita. 
Menurut Azria dan Husnah (2016), informasi yang diberikan pada ibu balita saat penyuluhan dapat menambah pengetahuan, semakin sering ibu mendapat informasi kesehatan semakin baik pula pengetahuan ibu tentang gizi seimbang balita, maka samakin baik dalam memperhitungkan jenis dan jumlah makanan yang diperolehnya untuk dikonsumsi (Azria, 2016).

\section{Sumber Informasi}

Penyuluhan gizi seimbang penting untuk meningkatkan pengetahuan gizi seimbang bagi ibu yang memiliki balita. Menurut Arikunto (2006), tingkat pengetahuan disebabkan oleh beberapa faktor, antara lain: umur dan tingkat pendidikan (Arikunto, 2006). Selain faktor umur dan tingkat pendidikan, kurangnya pengetahuan responden juga dikarenakan kurang adanya sosialisasi atau penyuluhan dari petugas kesehatan setempat mengenai kesehatan dan gizi. Dari hasil penelitian 34 responden yang diteliti, diperoleh hasil bahwa sebagian besar responden memperoleh sumber informasi tentang gizi seimbang pada balita diperoleh petugas kesehatan sebanyak 50\%. Peneliti belum menemukan hasil penelitian yang sejalan dengan hasil penelitian ini tentang cara ibu balita memperoleh sumber informasi tentang gizi seimbang balita.

Menurut Susilowati dan Himawati (2017), pengetahuan ibu tentang kebutuhan gizi yang dipahami dengan baik akan diiringi dengan perilaku pemberian makanan bergizi bagi balita. Pengetahuan bisa didapat dari informasi berbagai media elektronik dan media cetak seperti TV, radio, smartphone atau surat kabar seperti halnya dalam penelitian ini. Ibu mendapatkan informasi tentang kebutuhan gizi balita dari penyuluhan yang diberikan puskesmas setiap pelaksanaan program posyandu. Informasi ini meningkatkan pengetahuan yang diiringi dengan perilaku baru dalam pemberian makanan bergizi bagi balita sehingga status gizi pun menjadi baik. Upaya untuk meningkatkan pengetahuan gizikesehatan ibu melalui penyuluhan merupakan langkah yang tepat dilakukan oleh orang tua dan didukung oleh pihak-pihak yang peduli terhadap ibu dan anak. Hasil penelitian ini sejalan dengan penelitian Ditamarte tahun 2011, yaitu adanya pengaruh penyuluhan gizi terhadap pengetahuan ibu tentang gizi balita dengan metode simulasi setelah penyuluhan. 
Menurut Notoatmodjo (2014) pengetahuan atau knowledge adalah hasil penginderaan manusia atau hasil tahu seseorang terhadap suatu objek melalui pancaindra yang dimilikinya. Pengindraan terjadi melalui panca indra manusia, yakni indra penglihatan, pendengaran, penciuman, rasa dan raba. Pada penelitian ini pengetahuan ibu balita tentang gizi seimbang pada balita dapat diperoleh melalui indera penglihatan, dan pendengaran, yaitu dengan penyuluhan menggunakan media leaflet.

Berdasarkan tabel 6. didapatkan hasil bahwa perbedaan tingkat pengetahuan responden sebelum dan setelah diberikan penyuluhan kesehatan tentang gizi seimbang pada balita. terdapat 14 responden $(41,2 \%)$ dengan tingkat pengetahuan baik sebelum diberikan penyuluhan meningkat menjadi 24 responden $(70,6 \%)$, terdapat perbedaan tingkat pengetahuan sedang dan kurang jumlah responden setelah diberikan penyuluhan kesehatan, 9 responden (26,5\%) dengan tingkat pengetahuan sedang dan 1 responden (2,9\%) dengan tingkat pengetahuan kurang. Kemudian untuk melihat apakah perbedaan nilai pengetahuan sebelum dan sesudah bermakna benar-benar secara statistik maka dari uji stastitik Wilcoxon test dengan tingkat signifikansi $\alpha=0,05$ didapatkan $p$-value $=0,000$, artinya ada pengaruh penyuluhan kesehatan terhadap tingkat pengetahuan ibu tentang gizi seimbang balita di Posyandu Balita di RW 02 dan RW 03 Kelurahan Tingkir Lor. Terdapat 15 responden yang mengalami perubahan tingkat pengetahuan dominan ke arah positif (Positive Ranks), dan sebanyak 19 responden tidak mengalami peningkatan maupun penurunan pengetahuan (Ties Rank) dan tidak ada responden yang mengalami penurunan pengetahuan. Hasil penelitian ini menemukan bahwa penyuluhan kesehatan tentang gizi seimbang pada balita yang diberikan kepada ibu efektivitas dalam meningkatkan pengetahuan. Penyuluhan kesehatan adalah gabungan berbagai kegiatan dan kesempatan yang berlandaskan prinsipprinsip belajar untuk mencapai suatu keadaan, dimana individu, keluarga, kelompok atau masyarakat secara keseluruhan ingin hidup sehat, tahu bagaimana caranya dan melakukan apa yang bias dilakukan, secara perseorangan maupun secara kelompok dengan meminta pertolongan. 
Hasil penelitian ini didukung oleh hasil penelitian Azria dan Husnah tahun 2015 tentang pengaruh penyuluhan gizi terhadap pengetahuan dan perilaku ibu tentang gizi seimbang balita yang menyatakan bahwa terdapat peningkatan pengetahuan dan perubahan perilaku ibu kearah yang lebih baik setelah diberikan penyuluhan gizi balita (Azria, 2016). Menurut penelitian Leokuna (2013) menyatakan bahwa terdapat perbedaan pengetahuan ibu yang memiliki balita sebelum penyuluhan adalah 40,69\% mengalami peningkatan sesudah penyuluhan menjadi $78 \%$.

Terdapat kesesuaian antara fakta dan teori, dimana saat seseorang menerima penyuluhan maka hal tersebut akan meningkatkan pengetahuannya. Dalam hal ini pemberian informasi melalui proses penyuluhan dapat memberikan pengaruh jangka pendek terhadap pengetahuan responden mengenai gizi seimbang balita. Sehingga responden yang baru saja menerima informasi saat diberikan kuisioner mengenai gizi seimbang balita akan menjawab pertanyaan sesuai informasi yang telah diperoleh.

Penyuluhan dipengaruhi oleh beberapa faktor salah satunya adalah alat peraga dan metode yang digunakan dalam proses penyuluhan dan juga pemilihan waktu dan durasi penyajian materi. Berdasarkan kerucut Elgar Dale, jika tujuan pendidikan kesehatan hanya untuk mengubah pengetahuan maka teknik dan media baca (Slide dan leaflet) adalah yang paling tepat. Kerucut Elgar Dale menggambarkan kemampuan partisipasi seperti membaca, responden akan mengingat $10 \%$ materi yang dibaca, mendengar, responden akan mengingat $20 \%$ dari yang didengarnya. Partisipasi dalam diskusi, responden akan mengingat $70 \%$ dari apa yang diucapkannya (Nursalam, 2008). Pada penelitian ini, pengalaman dan cara responden memperoleh informasi tentang gizi seimbang pada balita adalah dari petugas kesehatan, media elektronik, dan media cetak.

Terdapat kesesuaian antara teori dan fakta dimana penggunaan alat peraga yaitu pemberian leaflet untuk menstimulasi penerimaan visual responden dalam membaca dan mendengarkan sehingga mempermudah responden dalam memahami informasi yang disampaikan, juga adanya kesempatan responden untuk berpartisipasi dalam diskusi dan terjadi komunikasi 2 arah yang dapat 
meningkatkan pengetahuan seseorang, sehingga terdapat peningkatan pengetahuan responden sebanyak $70,6 \%$ dan tidak terdapat responden yang mengalami penurunan tingkat pengetahuan. Hal ini membuktikan bahwa pemberian informasi kesehatan dapat memberikan kontribusi pada peningkatan pengetahuan seseorang dan merupakan upaya yang efektif yang dapat digunakan dalam penyampaian informasi.

\section{SIMPULAN}

Dari hasil penelitian ini didapatkan sebagian besar responden berumur 2035 tahun, berpendidkan SMA, yang tidak bekerja dengan status ibu rumah tangga, berstatus sudah memperoleh informasi dan memperoleh informasi dari petugas kesehatan. Terdapat perbedaan tingkat pengetahuan responden sebelum dan setelah diberikan penyuluhan kesehatan tentang gizi seimbang pada balita. Terdapat pengaruh penyuluhan kesehatan terhadap tingkat pengetahuan ibu tentang gizi seimbang balita secara statistik. Terdapat 15 responden yang mengalami perubahan tingkat pengetahuan dominan ke arah positif (Positive Ranks), dan sebanyak 19 responden tidak mengalami peningkatan maupun penurunan pengetahuan (Ties Rank) dan tidak ada responden yang mengalami penurunan pengetahuan. Simpulan hasil penelitian ini menemukan bahwa penyuluhan kesehatan tentang gizi seimbang pada balita yang diberikan kepada ibu efektivitas dalam meningkatkan pengetahuan.

\section{DAFTAR PUSTAKA}

Arikunto, S. (2006) Metode Penelitian Kualitatif. Jakarta: Bumi Aksara.

Azria, C. R. (2016) 'Pengaruh Penyuluhan Gizi Terhadap Pengetahuandan Perilaku Ibu Tentang Gizi Seimbang Balita Kota Banda Aceh', Jurnal Kedokteran Syiah Kuala, 16(2), pp. 87-92.
Ditamarte, L. (2011) Pengaruh Penyuluhan Gizi terhadap Pengetahuan Ibu tentang Gizi Balita Di Desa Argotirto Kabupaten Malang. UniversitasNegeri Malang. Available at: http://library.um.ac.id.

Handayani, I. (2008) Hubungan Antara Sosial Ekonomi Keluarga 
dengan Status Gizi Balita

Indonesia, Ipb.Ac.Id. Institute

Pertanian Bogor. Available at:

http://repository.ipb.ac.id.

Kemenkes RI (2015) 'Situasi anak balita di Indonesia'. Jakarta: Kemenkes RI.

Kementerian Kesehatan RI Badan Penelitian dan Pengembangan (2018) 'Hasil Utama Riset Kesehatan Dasar', Kementrian Kesehatan Republik Indonesia, pp. 1-100. doi: 1 Desember 2013.

Kusumaningtyas, D. A. (2011) Pengaruh Penyuluhan Gizi Terhadap Tingkat Pengetahuan Ibu Mengenai Pemberian Makanan Tambahan yang Baik untuk Balita. Universitas Sebelas Maret. Available at: https://eprints.uns.ac.id.

Leokuna, J. M. (2016) Pengetahuan Ibu tentang Gizi Balita Sebelum Sesudah Penyuluhan di RW 10 Kampung Citis Desa Cihanjung Bandung Barat tahun 2016. Universitas Advent Indonesia. Available at: https://docplayer.info.

N, S. (2009) Gambaran Pengetahuan Ibu Tentang Pola Pemberian
ASI, MP ASI dan Pola Penyakit

Pada Bayi 0-12 bulan di Dusun III Desa Limau Manis Kecamatan Tanjung Kabupaten Deli Serdang, USU Repository 2009. Universitas Sumatera Utara.

Notoatmodjo (2007) Kesehatan Masyarakat Ilmu Dan Seni. Jakarta: Rineka Cipta.

Notoatmodjo, S. (2014) Menjaga Kesehatan Balita. Jakarta: Rineka Cipta.

Novaria, T. (2014) Menjaga Kesehatan Balita. Surakarta: Platinum.

Nursalam (2008) Pendidikan dalam Keperawatan. Jakarta: Salemba Medika.

Rozali N, Subagyo B, W. E. (2016) 'Peranan Pendidikan, Pekerjaan Ibu Dan Pendapatan Keluarga Terhadap Status Gizi Balita di Posyandu Rw 24 dan 08 Wilayah Kerja Puskesmas Nusukan Kota Surakarta', eprints.ums.ac.id.

Sinuhaji L (2018) 'Efektifitas Penyuluhan Dan Media Leaflet Terhadap Pengetahuan Dan Sikap Ibu Balita Tentang Gizi Buruk di Dusun VII Desa Bangun rejo Kecamatan 
Tanjung Morawa Utara Tahun 2018. No Title', Jurnal Ilmiah Kohesi, 1.

Susanti, R., Indriati, G. and Utomo, W. (2014) 'Hubungan Pengetahuan Ibu Tentang Gizi Dengan Status Gizi Anak Usia 1-3 Tahun', Jurnal Online Psik, 1(2), pp. 17.

Susilowati, H. (2017) 'Hubungan

Tingkat Pengetahuan Ibu

Tentang Gizi Balita dengan

Status Gizi Balita di wilayah

Kerja Puskesmas Gajah 1
Demak', Jurnal Kebidanan, 6(13), pp. 21-25.

Tengah, D. K. P. J. (2018) 'Profil

Kesehatan Provinsi Jawa

Tengah Tahun 2018', Dinkes

Provinsi Jawa Tengah.

Semarang.

UNICEF (2013) 'Improving Child Nutrition: The Achievable Imperative for Global Progress. Division of Communication', UNICEF, pp. 1-2. Available at: www.unicef.org/publications/ind ex.html. 